\title{
CAMA
}

Centre for Applied Macroeconomic Analysis

\section{Climate change and monetary policy: Dealing with disruption}

\section{CAMA Working Paper 77/2017 \\ December 2017}

\section{Warwick McKibbin}

Centre for Applied Macroeconomic Analysis, ANU

Brookings Institution

\section{Adele Morris}

Brookings Institution

Centre for Applied Macroeconomic Analysis, ANU

\section{Augustus J. Panton}

Centre for Applied Macroeconomic Analysis, ANU

\section{Peter J. Wilcoxen}

Syracuse University

Brookings Institution

\section{Abstract}

This paper explores the interaction of monetary policy and climate change as they jointly influence macroeconomic outcomes. In bringing together the literatures on climate change and monetary policy, we seek to alert policymakers in each realm to the implications of the other. 


\section{Keywords}

JEL Classification

Address for correspondence:

(E) cama.admin@anu.edu.au

ISSN 2206-0332

The Centre for Applied Macroeconomic Analysis in the Crawford School of Public Policy has been established to build strong links between professional macroeconomists. It provides a forum for quality macroeconomic research and discussion of policy issues between academia, government and the private sector.

The Crawford School of Public Policy is the Australian National University's public policy school, serving and influencing Australia, Asia and the Pacific through advanced policy research, graduate and executive education, and policy impact. 


\title{
CLIMATE CHANGE AND MONETARY POLICY: DEALING WITH DISRUPTION
}

NOVEMBER 30, 2017

\author{
WARWICK J. MCKIBBIN \\ Australian National University \\ Brookings \\ ADELE C. MORRIS \\ Brookings \\ PETER J. WILCOXEN \\ Syracuse University \\ Brookings \\ AUGUSTUS J. PANTON \\ Australian National University
}

The authors thank Louise Sheiner and Donald Kohn for very helpful comments.

The Brookings Institution is a private non-profit organization. Its mission is to conduct high quality, independent research and, based on that research, to provide innovative, practical recommendations for policymakers and the public. The conclusions and recommendations of any Brookings publication are solely those of its author(s), and do not reflect the views of the Institution, its management, or its other scholars. Support for this publication was generously provided by the Alex C. Walker Foundation. Brookings recognizes that the value it provides is in its absolute commitment to quality, independence and impact. Activities supported by its donors reflect this commitment, and the analysis and recommendations are not determined or influenced by any donation. 


\section{INTRODUCTION}

This paper explores the interaction of monetary policy and climate change as they jointly influence macroeconomic outcomes. In bringing together the literatures on climate change and monetary policy, we seek to alert policymakers in each realm to the implications of the other. The challenge that closely connects climate change and monetary policy is the potential for and response to economic "shocks." These are abrupt events that increase or decrease the demands for goods and services (demand shocks) or increase or decrease the supply or cost of goods and services (supply shocks). When a shock applies to goods and services generally, rather than any specific one, we call it an aggregate shock. A shock can be temporary (a.k.a. transitory) or involve more permanent changes in the economy. For example, a trade embargo can produce a transitory negative supply shock, and a new technological improvement can produce a permanent positive supply shock.

One can think of the impacts of climatic disruption and ambitious climate policy as supply shocks, some aspects of which would be transitory and some of which would be permanent. For example, extreme weather events and sea level rise can result in damages to crops, flooding of major cities and industrial areas, coastal erosion that destroys property and physical plant, extensive power outages, infrastructure damage, and the dislocation of workers. These are all negative supply shocks. ' Spikes in crop prices might be temporary, but sea level rise may permanently destroy productive coastal land. An abrupt and stringent constraint on GHG emissions can permanently increase the prices of fossil fuels, but the degree to which it makes existing capital uneconomic is transitory.

We proceed in three parts. First, the paper reviews basic emissions mitigation policy options and the different ways in which they can impact output, prices of particular goods, and overall price levels. It also reflects on how the manifestations of climatic disruption can impact prices and output levels. Such outcomes can affect central banks' ability to forecast and manage inflation.

Second, in laymen's terms we review the basic approaches to monetary policy, including various types of inflation and output targeting. We also explain some other responsibilities that may fall to central bankers, depending on the laws in their country. Finally, we bring together the two sets of issues and concerns to consider the optimal monetary framework in a carbonconstrained and climatically-disrupted world and to highlight the climate policy frameworks that can make monetary policies more efficient and effective. A core message of this paper is that policy responses to climate change can have important implications for monetary policy and vice versa. Different approaches to imposing a price on carbon will impact energy and other prices differently; some would provide stable and predictable price outcomes, and others could

\footnotetext{
' Climate change can also result in positive supply shocks in some locations, for example if changing rainfall patterns or longer growing seasons improve agricultural output.
} 
be more volatile. All else equal, more volatile prices pose greater challenges to central bank authorities than more predictable prices, in part because they complicate the forecasting of inflation and other economic variables that central banks use to benchmark their policies.

Similarly, ambitious climate policy can affect output, both in aggregate and disproportionately in select emissions-intensive sectors. Policies that are the least costly and most predictable can minimize the extent to which monetary policymakers must anticipate their effects in their overall stewardship of the macroeconomy.

Likewise, monetary policy could have important impacts on the macroeconomic outcomes of emissions abatement policy and extreme weather events. For instance, if continuously rising prices from carbon constraints induce the central bank to raise interest rates to slow inflation, this would exacerbate the fall in overall economic activity from the carbon policy, thus lowering gross domestic production (GDP), employment, and welfare relative to other ways a central bank could react. Second, a sustained rise in the relative price of carbon could enter into wage negotiations, for example if workers anticipate a decline in the buying power of their earnings. In this case, an inappropriate monetary policy response could lead to a wage-price spiral as people find it harder to forecast inflation and therefore lose an important anchor for inflationary expectations. This could lead to a costly long-lived inflationary process.

Thus, in light of the urgency of ambitious climate action, we contend that these policy spheres should be brought together more explicitly. Moreover, there is a clear conceptual foundation for doing so. From a monetary perspective, climate change and climate policy are both supply shocks, and the monetary policy literature has long emphasized the importance of supply shocks in the choice of a monetary regime. Thus, the insights from this large historical literature can inform the climate/monetary policy discussion of today. To our knowledge this paper takes the first step explicitly draw out the link between monetary policy and climate policy regime design.

Section 2 reviews basic design options for emissions abatement and related evidence on how a carbon price can affect both relative prices and overall price levels. Section 3 explains the primary monetary policy options under debate in the macroeconomic literature. Section 4 brings together the challenges raised by climate change and the options for monetary authorities with an eye to jointly optimizing the two. It also offers some thoughts about the other central bank responsibilities that may come to bear on the risks and opportunities associated with climate change. Section 5 concludes. 


\section{CLIMATE POLICY}

In this section, we discuss basic options for greenhouse (GHG) emissions mitigation policy, which fall broadly into two categories: (I) establishing an explicit, economy-wide price for emitting carbon dioxide $\left(\mathrm{CO}_{2}\right)$ and other $\mathrm{GHGs}$, or (2) adopting a suite of regulatory measures and subsidies. Any of these approaches can impose burdens on the economy, but they also provide environmental benefits that can justify their costs. Although we focus here on the economic costs of climate policy, we emphasize that important positive net benefits can accrue from efficiently controlling GHG emissions and reducing the risks of climatic disruption and ocean acidification. The design details of these approaches have different implications for monetary policy, so we will discuss each one in more detail below. We use the terms carbon tax and carbon pricing as shorthand for policies that put a price on GHG emissions generally, to the extent feasible.

\section{Carbon Pricing}

Economists widely agree that the most efficient approach to reducing GHG emissions is to establish a price on those emissions. Policymakers can set the price directly on fossil-fuelrelated carbon dioxide, the largest constituent of overall GHG emissions, and a number of other GHG emissions via a tax. For fossil $\mathrm{CO}_{2}$, the tax could fall on the carbon content of fossil fuels or on the $\mathrm{CO}_{2}$ emitted when the fuels are burned. Alternatively, policymakers can impose a price indirectly through a tradable permit system, or through a hybrid policy that has a mix of the characteristics of tax and permit programs.

\section{Carbon Taxes}

A carbon tax is the most direct and transparent approach for establishing a price on emissions. Policymakers have many options for the design of a carbon tax trajectory and the related provisions of the policy, including how the revenue is used. ${ }^{2}$ For example, the tax could be set equal to an estimate of the marginal social cost of carbon (SCC) in order to internalize the externalities associated with climate change, or it be designed to achieve a particular emissions or revenue goal. ${ }^{3}$ A typical proposal would set a starting value for the tax and specify a rate at which the tax should rise over time in real terms. Periodic adjustments to the trajectory may be necessary to hit a particular long term emissions goal.

\footnotetext{
${ }^{2}$ https://www.brookings.edu/research/I I-essential-questions-for-designing-a-policy-to-price-carbon/ ${ }^{3}$ A review of this literature can be found in Marron and Toder (20I4). Calculating the SCC is difficult and imprecise. Due to the uncertainties on the future path of greenhouse gas emissions and the discount rate used in measuring intertemporal climate damages, there are large differences in the estimates of SCC provided using integrated assessment models (Nordhaus, 1993; Stern, 2007; Nordhaus, 20I4), with some critics questioning the usefulness of such estimates (Pindyck, 2013; 2015).
} 
The magnitude of the requisite carbon tax can depend on the emissions goal and, importantly, when the policy starts. Figure I shows an example of an illustrative carbon tax trajectory that achieves a specified cumulative emissions goal. In this particular example, McKibbin, Morris and Wilcoxen (20l4) compare carbon price trajectories under three alternative assumptions about U.S. climate policy. Each policy achieves the same cumulative emissions reduction relative to a no-policy baseline over a period of 24 years. The policies vary by starting date, initial tax rate, and growth rate. The vertical lines at years $I$ and 9 to indicate the effective dates of the policies. Under SI_now, the tax starts in year I at $\$ I 5$ per ton of $\mathrm{CO}_{2}$ and rises by 4 percent above the rate of inflation each year until it reaches the peak of $\$ 67$, after which it is held constant. The other two policies start eight years later, in year 9, but have to make up for lost time with more ambitious policy. Under S2_step, the carbon tax starts at a higher initial rate, $\$ 25.50$, and rises at the same 4 percent annually in real terms. The tax in the third scenario, S3_rate, starts at $\$ 15$ per ton (in constant dollars), but has to grow much more quickly, at about 10 percent real each year. Thus we find that to achieve the same the cumulative emissions, a delayed policy must have a starting carbon tax rate that is 70 percent higher or a growth rate more than double that of a policy that starts now.

Figure I: The Tax Rate per Metric Ton of Carbon Dioxide

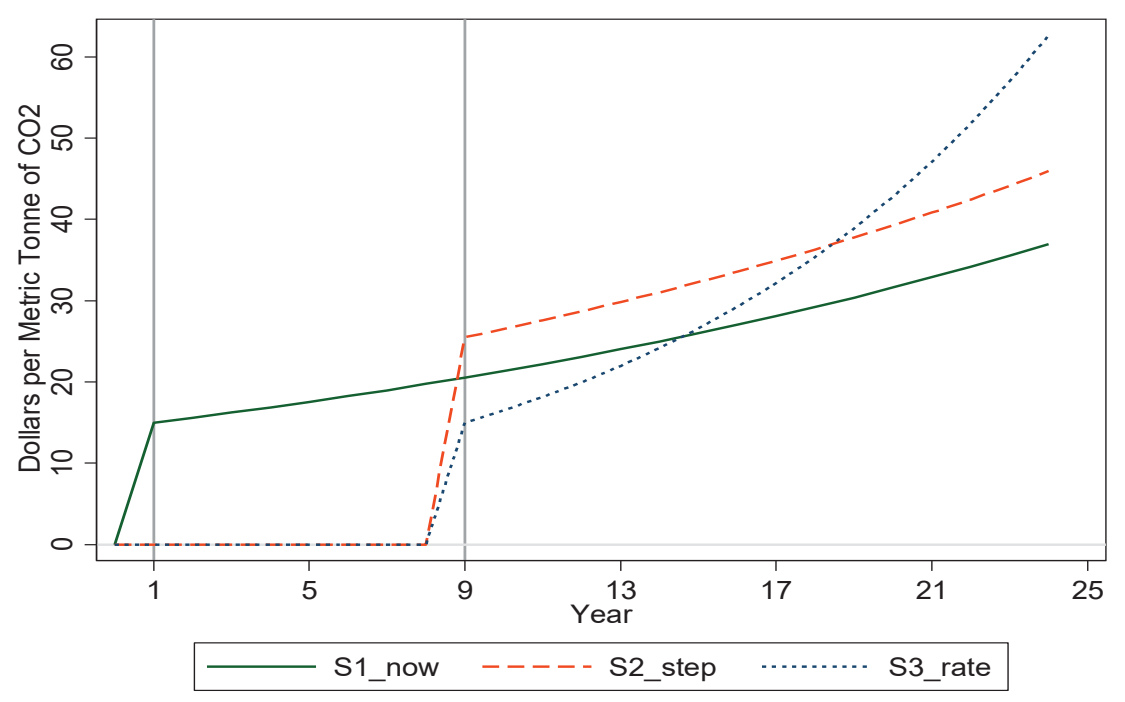

Source: McKibbin, Morris and Wilcoxen (2014)

A carbon tax will affect the prices of different fuels and other goods and services differently, depending on their carbon intensity. Coal is the most carbon intensive fossil fuel, so its price would go up the most. For example, the U.S. Treasury estimates that a carbon tax of $\$ 49$ per metric ton of $\mathrm{CO}_{2}$ would translate to a tax of about $\$ 110$ per short ton of bituminous coal, one of the largest categories of coal produced in the United States. ${ }^{4}$ That tax would be more than

\footnotetext{
${ }^{4}$ https://www.treasury.gov/resource-center/tax-policy/tax-analysis/Documents/WP-II5.pdf
} 
twice what power plants, coal's largest market, now pay for coal. ${ }^{5}$ Natural gas, an important competitor of coal in the power sector, contains about half the carbon of coal per unit energy, resulting in a substantially lower relative price increase for the same carbon tax. For gasoline, a $\$ 49$ per ton $\mathrm{CO}_{2}$ tax would amount to about $\$ 0.44$ per gallon of gasoline. All of these price increases would ripple through the economy and increase the prices of other goods and services, depending on how much, and which, fossil fuels are in their supply chain. The sum of all those ripple effects will be an increase in the overall nominal price level.

The impact on real price levels depends on how monetary policymakers respond to the increase in nominal price levels. McKibbin et al. (20/4) model a carbon tax imposed in the United States. In their results, which assume the Fed follows a Taylor rule, a $\$ 15$ per ton carbon tax causes a rise in inflation of $0.8 \%$ in the first year of the policy. Thus, the impact on real energy prices is about I percent smaller than the impact on nominal prices.

For our purposes in this paper, a carbon tax has three key features: $(I)$ the trajectory of the tax is known in advance; (2) there will be a significant initial impact on the price level when the tax is first established; and (3) the growth of the tax in real terms over time will introduce an upward trend in prices and, other things equal, push the economy toward a higher overall rate of inflation, at least through the medium run. In addition, although a carbon tax establishes a predictable price, its impact on emissions will vary from year to year with economic conditions, technological change, and other factors.

Research has shown that the ultimate economic impact of a carbon tax depends on how the revenue it raises is used. For example, reducing marginal rates on other taxes, such as those on labor and capital can reduce the distortions in those markets and thus offset some of the macroeconomic burden of the carbon tax (Pearce, 1991; Metcalf, 2007). McKibbin, et al. (2012) find that using carbon-tax generated revenue to offset capital income tax burdens leads to a more pro-growth effect of a carbon tax on the US economy. In contrast, Metcalf (2007a) and Perry and Williams (20II) find that using the revenues to reduce labor taxes generates higher welfare gains than when used to reduce capital taxes. Although there is no empirical consensus on the optimal use of the tax revenues, not least because these approaches also have importantly different distributional consequences, there is a strong consensus that carbon tax policies whose revenues are recycled efficiently can promote emissions abatement while also helping to reduce existing tax distortions in the economy.

\section{Tradable Permits}

An alternative way to limit GHG emissions would be to establish a system of tradable emissions permits. For example, a regulator could require fossil fuel producers or users to have a permit for each metric ton of carbon dioxide emissions that would be associated with those fuels. The

\footnotetext{
${ }^{5}$ https://www.eia.gov/coal/annual/
} 
regulator would then choose a target level of emissions for each year, issue that number of permits (a range of mechanisms for distributing permits have been discussed in the literature), and allow trading. To emit a ton of carbon dioxide, a fuel user would need to buy a permit at the market price (or would have to forego selling a permit at that price), so the market price would become the de facto price of emitting carbon dioxide. This approach establishes a predictable amount of emissions. With a fixed supply of permits (assuming no banking or borrowing across compliance periods), any change in the demand for permits, such as fluctuations in economic conditions, will cause the carbon price to vary from year to year along a vertical supply curve for permits. Thus, for the purposes of monetary policy, this approach is quite different from a carbon tax: ( $I$ ) the number of permits (and hence the level of emissions) in each future year may be known in advance; but (2) the initial price would not be known in advance and would be determined by market forces after the policy was implemented; and (3) the rate of growth of the price would be determined by market forces as well.

Both the implementation of the policy and business cycle shifts can greatly influence the level and volatility of permit prices in a cap-and-trade system. For example, the program can allow banking and borrowing of emissions allowances across compliance periods or establish a floor and ceiling on permit prices. ${ }^{6}$

To illustrate the potential volatility of emissions permit prices in practice, Figure 2 reports the history of the futures prices of the emissions allowances in the European Union's Emissions Trading System (ETS). ${ }^{7}$ Some of the factors that contributed to the volatility included an inadvertent oversupply of allowances in early phases of the program and a major financial and economic crisis in 2008 that dramatically reduced demand for allowances.

\footnotetext{
${ }^{6}$ An extensive literature explores design options for emissions permit trading systems. For example, see Fell et al. (2012).

${ }^{7}$ Unit of trading: One lot of 1000 Emission Allowances. Each Emission Allowance is an entitlement to emit one metric ton of carbon dioxide equivalent gas. Contract Series: Consecutive contract months to March 2008 and then December contract months only from December 2008 to December 2012.
} 
Figure 2. Futures price of allowances in EU ETS from Jan 2005 to October 2017

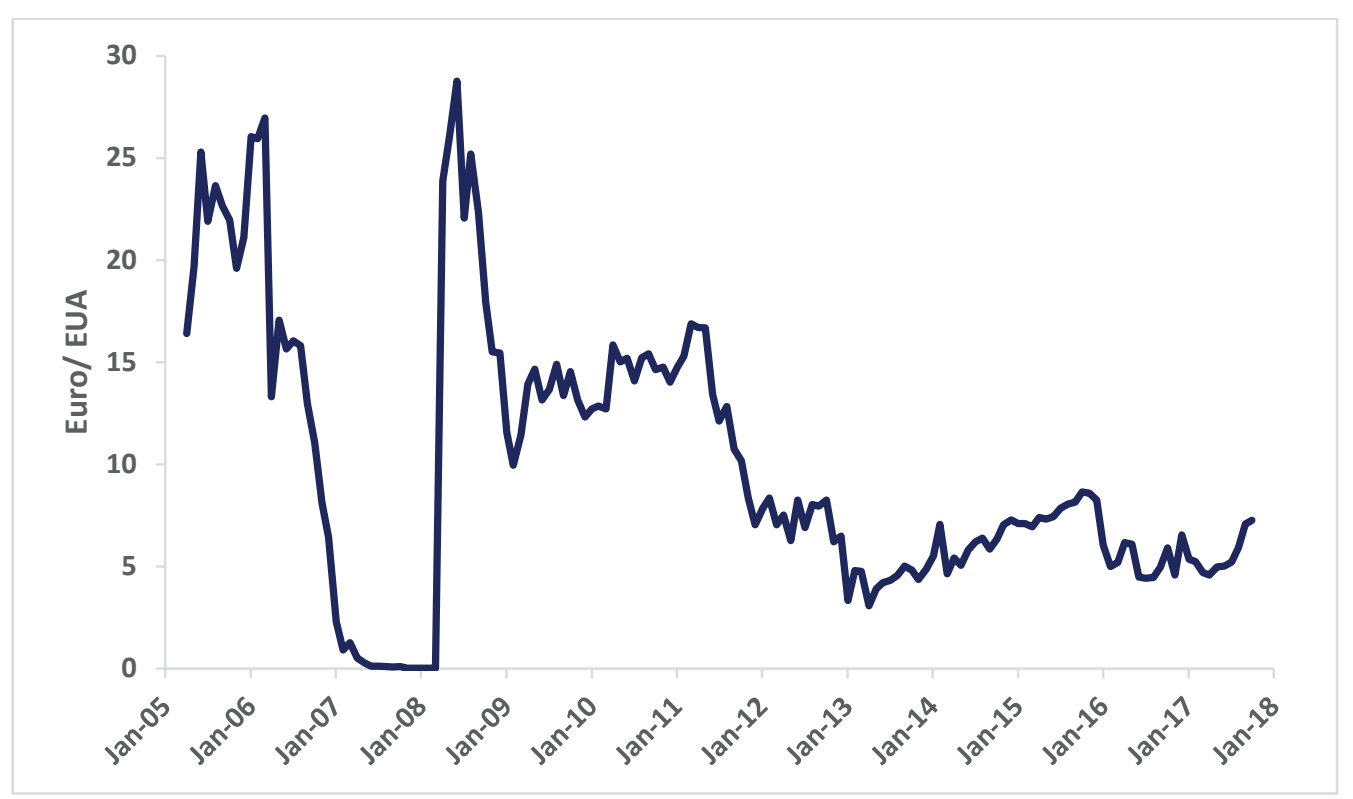

Source: Bloomberg

\section{Hybrid Policies}

A third approach would be a hybrid of the tax and permit policies. One such policy has been advocated by McKibbin and Wilcoxen (2002). This approach is analogous to how the U.S. Federal Reserve (the Fed) sets short term interest rates while the bond market sets the longterm interest rate through market transactions (McKibbin, 20I2). In this policy, the long run quantity of emissions (the annual allowance of all permits for each year into the future) is set and allocated to current individuals and firms. An agency that might be called a "central bank of carbon" then announces a short-term maximum carbon price, or price ceiling, much like the Fed announces a short-term interest rate. It makes available as many annual permits as demanded at the ceiling price, effectively capping the price of carbon in any given year. If a small number of long term permits are made available in the early years of the policy then the short term carbon price cap will always be binding unless there is a substantial reduction in emission at low cost. The long-term price of carbon, however, will be determined in the futures market (much like the long term bond market) where the carbon targets are balanced against expectations of future short term prices, where each year's expectation is either the market equilibrium price in that year or the ceiling price set by the agency, whichever is lower. Thus, the short term price is equivalent to a carbon tax (when the cap is binding, which is likely if few long term permits are issued), but the long term price is determined by a futures market. In terms of its impact on monetary policy, a hybrid policy would be midway between standard tax or permit policies. It would: (I) establish a ceiling price trajectory known in advance; but (2) 
allow actual prices to be lower than the ceiling when market conditions warrant; and (3) allow variation in emissions from year to year.

McKibbin, Morris and Wilcoxen (2009) show that a carbon tax, permit trading system and a Hybrid have very different properties in the face of global economic shocks. For example, suppose China has a growth boom. Under a global carbon tax this would result in higher global emissions but the rise in productivity in China would be positively transmitted to other countries through international trade. Under a global permit trading system - the boom in China would raise the global price of carbon permits which would be a negative shock for countries outside China because the price of carbon intensive energy inputs would rise. The positive trade effects can be completely negated by the negative impact of higher global carbon prices. This can on balance be negative for countries that do not trade much with China. A Hybrid policy acts like a carbon tax in this case.

Conversely, under a carbon tax a global financial crisis which reduces global demand for carbon-intensive energy will lead to a fall in global emissions. However, under a permit trading system, the lower demand for carbon-intensive energy results in a lower carbon price for the fixed target for emissions. The policy would then be countercyclical (or stabilizing) in the sense that lower carbon prices would help offset the negative shock from the financial crisis.

Interestingly, the Hybrid policy acts like a carbon trading system under the financial crisis shock because there is only a ceiling price but no floor on carbon prices under a Hybrid. Thus carbon price can fall if a shock reduces the demand for carbon intensive energy. This distinction between the three climate policy regimes is critical in a world of large macroeconomic shocks.

\section{Non-Price Emissions Abatement Policies}

Although pricing carbon and other GHGs has many attractive features, a number of other climate policies have been proposed as well. For example, the U.S. Environmental Protection Agency (EPA) drafted the Clean Power Plan as a regulatory approach to reducing emissions from the electric sector. Under that regulation, states would have been required to achieve specified targets for average $\mathrm{CO}_{2}$ emissions per kilowatt hour of electricity generated or a total mass limit of $\mathrm{CO}_{2}$ from existing power plants. Other policies aimed at reducing emissions include: tighter fuel efficiency standards for vehicles; production and investment tax credits for renewable electricity; renewable portfolio standards for electric utilities; and tax credits for a range of goods such as residential solar systems, electric vehicles, and home and business weatherization. At their core, these policies impose implicit prices on the use of fossil fuels because they impose a cost or monetary incentive on incremental emissions-reducing activities. However, unlike the explicit carbon pricing policies discussed above, the prices are not directly observable, differ from one sector to the next, and do not have clear, predictable trajectories. They are also likely to yield higher carbon prices because of the nature of the policy. As a result, accounting for them in setting monetary policy is far more difficult. For example, a regulatory approach like the Clean Power Plan can raise electricity prices by amounts that are 
hard to predict and differ significantly across the country owing to regional variations in stringency and implementation strategy.

\section{Policy Impacts}

Whether implemented as a broad-based emissions price or as a suite of narrower actions, a carbon abatement policy affects the economy in two ways. First, it increases production costs and the relative prices of carbon-intensive goods and services, negatively affecting real wages, consumption, investment and, ultimately, output. Second, the policy may exacerbate the distortionary effects of existing taxes in the economy, particularly in the labor market. ${ }^{8}$ This occurs because existing taxes on labor income reduce the incentive to work by reducing the returns to labor. ${ }^{9}$ A carbon tax raises price levels, thereby lowering the real wage, further decreasing the incentive to work and exacerbating the existing distortions in the labor market. This "tax interaction effect" has been shown to be potentially quite large, suggesting the benefits to using the carbon tax revenue to reduce other tax rates may be significant. Indeed, modeling has supported this finding (McKibbin et al, 20I2).

In the long run, as long as each climate regime is designed to achieve the same emissions target over the same time frame, the policies will be similar. In the short-run however, the various climate policy frameworks can produce different inflation and output dynamics. In particular, it is this that maters for the short run response of monetary policy.

\section{MONETARY POLICY}

The primary monetary policy objective of most central banks around the world is to promote and maintain price stability; output stability and other macroeconomic outcomes are generally secondary objectives. In the United States, however, the Federal Reserve (the "Fed") has three coequal goals: maximum employment, stable prices, and moderate long-term interest rates. The Fed can pursue these goals by managing short-term interest rates and thereby influencing the cost and availability of credit in the U.S. economy. In particular, the Federal Open Market Committee (FOMC) can raise or lower its target for the federal funds rate, the interest rate banks charge each other for borrowing overnight. These interest rates have effects that can spill over into broader lending markets, affect spending decisions by households and businesses. Each of these interventions will also change the value of the U.S. dollar relative to other currencies, which impacts imports, exports, and international capital flows.

\footnotetext{
${ }^{8}$ Pearce, 199I; Goulder et al, 1997; Feldstein, 2006

${ }^{9} \mathrm{CBO}, 2013$
} 
There is a long running debate in the literature on how a central bank should implement its mandate. A central bank could respond to shocks with full discretion. Alternatively, it could follow a rule for how it will set its interest rates in response to shocks. One possible advantage of rules over discretion is that a rules-based approach is easier to communicate and thus allows financial markets to anticipate the likely response of the central bank to any particular economic shock.

Many academic macroeconomists argue that monetary policy rules provide more stable output and prices and are superior to unconstrained discretion. However, many central bank practitioners argue that monetary policy should be systematic, not automatic. ${ }^{10}$ The key remaining question in the literature is the best design of the monetary rule. There have been many proposed options: interest rate targets; money supply targets; exchange rate targets; inflation targets; Henderson McKibbin Taylor Rules (Henderson and McKibbin, 1993; Taylor 1993) that balance inflation and output changes; and nominal GDP (Frankel, 20I3) or nominal income targeting. " Each of these approaches has advantages and disadvantages, some of which depend on the kinds of shocks and business cycle outcomes that an economy experiences. Emissions mitigation policies and extreme weather events both present shocks that may affect which monetary rule would be most optimal. Below we consider the different rule options with an eye to identifying the strengths and weaknesses that are most applicable to climate-related outcomes. The nature and magnitude of climate-related shocks will vary by country, so these issues will have to be considered in context. Here we give special attention to the Fed, which does not follow a rule-based approach, but does have a framework which informs its decision making. The analysis might be different for other central banks that face different shocks or have different statutory objectives.

A very large literature focuses on rules for balancing output and inflation goals. This literature tends to compare how different monetary rules perform in the face of different shocks in the economy: real demand shocks, money velocity shocks, aggregate supply shocks, or economy wide risk shocks (Poole, 1972; McKibbin and Henderson, 1993). It also analyzes the ability of each rule to tie down inflationary expectations, and it examines the role of forecasting and predictability in minimizing volatility in the real economy. Each of these issues are important when considering the impact of climate policy on the design of monetary policy.

Most monetary policy regimes are reasonably good at handling demand shocks. For example, if aggregate demand rises and both output and inflation increase, all of the monetary rules would have the central bank raise interest rates. This would offset the shock's effects on inflation and output. In theory, under some economic conditions (called a "divine coincidence" in the

\footnotetext{
${ }^{10}$ See Bernanke (20I5).

" See McKibbin (20I5). Nominal GDP is a measure of the measures value of production whereas nominal income is a measure of income from production. The two are not equal in an economy where capital is owned by foreign residents and the income from that production accrues to foreigners.
} 
literature), an interest rate rule used to address a demand shock could simultaneously achieve a central bank's goals for inflation and output stability without trading one goal off against the other. While some evidence (Blanchard and Gali, 2007) suggests that this may be true for the Fed, recent empirical findings strongly uphold the traditional view (Alves, 20I4; Kim, 20I6) that such trade-off exists in practice. Thus, many rules have been proposed that differ in how they balance impacts on inflation and output for demand shocks, and the preferences of policymakers lead central banks to choose different rules.

The largest differences between monetary rules, however, arise from: (I) the way they handle supply shocks, where it is generally not possible (even in theory) for a single action to adequately address both output and inflation; and (2) how effective they are at providing a firm basis for private agents to form correct expectations about future inflation. We now turn to the various monetary rule options with an eye to understanding how they may handle such situations.

\section{Inflation Targeting}

A strict inflation targeting (IT) rule tells a central bank how to adjust interest rates in order to achieve a desired inflation target without any consideration of output or other variables. For example, Equation (I) shows a rule for the nominal interest rate $i$ set by the central bank in period $t$. The rate, $i_{t}$, is set equal to its value from the previous period, $i_{t-1}$, plus a feedback term that raises or lowers interest rates whenever actual inflation, $\pi_{t}$, is above or below the bank's target rate, $\bar{\pi}_{t}$ :

$$
i_{t}=i_{t-1}+\alpha\left(\pi_{t}-\bar{\pi}_{t}\right)
$$

Coefficient $\alpha$ in this and subsequent rules governs how aggressively the bank responds to deviations from its target. A large value of $\alpha$ would cause the rule to approximate exact inflation targeting: the central bank would make very large changes in interest rates in response to even small deviations in inflation and thus returning to the goal very quickly. In practice, $\alpha$ would be much smaller, so that the central bank would be targeting inflation with gradual adjustments over time - in effect putting weight on the output consequences.

Strict inflation targeting responds to all shocks equally, no matter what caused them, in an attempt to exactly stabilize inflation (Svensson 1998, 2003). However, the Fed's mandate, as well as those of most other central banks, also involves other considerations, such as maintaining high employment and output. As a result, central banks that use inflation targeting almost always follow an approach known as "Flexible Inflation Targeting" (FIT) in which they exercise discretion over when to follow the rule (Bernanke et al, 1999; Giannoni and Woodford, 2004). Flexible inflation targeting (FIT) allows central banks to strike various tradeoffs between changes in inflation and other objectives (King, 1997; Bernanke et al. 1999; 
Røisland, 200I). In particular, central banks using FIT may delay or moderate policy adjustments when they judge that following the rule too closely would cause excessive harm to their other goals, such as maintaining output and employment. The Fed is an example of a central bank that follows a FIT rule: it has an inflation target, but it also announces how other variables, such as employment, affect how rapidly it will attempt to return inflation to its target.

In practice, central banks that use inflation targeting follow a more sophisticated approach than that shown in Equation I. Generally, the rules are not driven by current inflation but rather by forecasts of inflation over some future period, meaning that the banks must anticipate how the economy will adjust over future periods to a change in policy today. An example appears in Equation 2 below, where $\pi_{t, t+1}$ is the bank's forecast at time $t$ of the inflation rate at time $t+1$ :

$$
i_{t}=i_{t-1}+\alpha\left(\pi_{t, t+1}-\bar{\pi}_{t}\right)
$$

That means an accurate forecast of inflation is critical to the central bank's success and credibility. And key to that is measurement of the output gap: the difference between actual and potential output ${ }^{12}$ of the economy. For example, a forecasting rule might be that inflation will be the target rate adjusted by an increasing function $f$ of the difference between real output of the economy, $Y_{t}$, and the central bank's assessment of the economy's maximum potential output, $\bar{Y}_{t}$ :

$$
\pi_{t, t+1}=\bar{\pi}_{t}+f\left(Y_{t}-\bar{Y}_{t}\right)
$$

If actual output is equal to potential output, the bank will expect inflation to be at its target rate $\bar{\pi}_{t}$. In contrast, if actual output is below potential output, then it will expect inflation to be lower than $\bar{\pi}_{t}$, and if output is above potential output, then it will expect inflation above $\bar{\pi}_{t}$. However, both $Y_{t}$ and $\bar{Y}_{t}$ will be estimates and are inherently uncertain. Thus, the central bank may get the output gap wrong and thus use a poor forecast of inflation in its targeting strategy.

\section{Price Level Targeting}

Price level targeting (PLT) is similar to inflation targeting, but the target is the price level itself rather than the inflation rate. An example for setting central bank interest rates with PLT appears in Equation 2, where the actual price level is $P_{t}$ and the target level is $\bar{P}_{t}$ :

$$
i_{t}=i_{t-1}+\alpha\left(P_{t}-\bar{P}_{t}\right)
$$

In practice, price level targeting would be used with a target that includes a trend. This type of monetary rule is said to have strong "historical dependence" because if there is a rise in

\footnotetext{
12 Potential output is the maximum sustainable output the economy could produce given: (I) optimal use of the economy's supplies of labor, capital and other primary factors; and (2) the levels of total and factor-specific productivity.
} 
inflation, the central bank not only acts to eliminate the inflation but induces a period of deflation (or inflation below the target price trend) in order to get the price level to return to its target trajectory. In this sense the initial price level casts a long shadow of the future path of prices.

With the core objective of maintaining the price level along the desired path by compensating lower past inflation with higher current inflation, PLT is an effective policy rule for anchoring expectations as long as private agents correctly account for its implicit history dependence (Svensson, 1996). However, if private agents do not form their expectations in accordance with monetary policy rules (Amano et al., 20I I), PLT may not be effective, leading to high inflation and output variability. Bernanke (2017) has recently made a strong case supporting temporary PLT in the case when interest rates are stuck at the zero lower bound.

\section{Henderson-McKibbin-Taylor Rules}

In contrast to rules focused only on inflation or the price level, Henderson-McKibbin Taylor (HMT) rules include an explicit balancing of a central bank's goals of price and output stability. Henderson and McKibbin (1993) outlined a general set of rules that specified the way in which interest rates could respond to both inflation and the output gap. This is shown in equation (5):

$$
i_{t}=i_{t-1}+\alpha\left(\pi_{t}-\bar{\pi}_{\mathrm{t}}\right)+\beta\left(Y_{t}-\bar{Y}_{t}\right)
$$

Parameters $\alpha$ and $\beta$ govern how the central bank balances its goals for inflation and output. They can be determined by the preferences of policy makers or could be calculated optimally given the structure of the economy. ${ }^{13}$ They showed that these parameters are especially dependent on the stickiness of nominal wages, meaning the tendency of wages to respond slowly to changes in the performance of a company or the broader economy. Taylor (1993) used this general form of the rule and selected specific values of $\alpha$ and $\beta$ to replicate the historical behavior of the Fed between 1984 and 1992. Others have since econometrically estimated the parameters of the HMT rule for the Fed and found results close to Taylor's original calibration.

A more general HMT rule is estimated using the G-Cubed multi-country model (McKibbin and Wilcoxen, 2013). G-Cubed allows the modeling of a wide variety of central bank policy rules, including: exchange rate targeting, money supply targeting, or a variety of explicit trade-offs between variables that reflect policies adopted by central banks in different countries. Equation (6), for example, is a generalization of equation (5) that includes potential weights on the exchange rate $\left(e_{t}\right.$ with target $\left.\bar{e}_{t}\right)$ and the money supply $\left(M_{t}\right.$ with target $\left.\bar{M}_{t}\right)$.

$$
i_{t}=i_{t-1}+\alpha\left(\pi_{t}-\bar{\pi}_{t}\right)+\beta\left(Y_{t}-\bar{Y}_{t}\right)+\delta\left(e_{t}-\bar{e}_{t}\right)+\sigma\left(M_{t}-\bar{M}_{t}\right)
$$

\footnotetext{
${ }^{13}$ Typically, the latter would be done by representing the central bank's objective via a loss function that is quadratic in deviations in inflation and output. The parameters of the rule would then be chosen to minimize the expected loss.
} 
These additional terms allow the equation to represent a wide variety of rules. For example, a central bank in a small country that aims to peg its currency to the U.S. dollar would have $\alpha=\beta=\sigma=0$ and a very large value for $\delta$. The Bank of China, on the other hand, might be represented by a rule with roughly equal values for $\alpha, \beta$, and $\delta$ (that is, assigning equal importance to the first three objectives) and set $\sigma=0$.

\section{Nominal Income and Nominal GDP Targeting}

Monetary policymakers can target a measure of nominal economic activity instead of inflation or price levels. This means that they try to avoid recessions (in nominal terms) to maintain a steady increase in economic activity or a particular rate of growth. There are at least two measures of economic activity that they could target. Nominal GDP is a measure of the output of an economy at current prices. Nominal income is a measure of the value of income generated by economic activities, including by individuals and businesses, measured at current prices. In the U.S. economy, the two concepts are similar. In a small open economy with a large amount of foreign capital, the two measures diverge due to payments of dividends to foreign capital owners. In the following discussion, we will use nominal income targeting (NIT) as shorthand for both types of rules. Equation 7 represents a nominal income rule where nominal income is represented by $P Y_{t}$ and the bank's target for it is $\overline{P Y}_{t}$ :

$$
i_{t}=i_{t-1}+\alpha\left(P Y_{t}-\overline{P Y}_{\mathrm{t}}\right)
$$

The rule can also be expressed in terms of the rate of change in nominal income, where $g_{t}$ is the growth rate of nominal income rather than its level, and $\bar{g}_{t}$ is the bank's target:

$$
i_{t}=i_{t-1}+\alpha\left(g_{t}-\bar{g}_{t}\right)
$$

There is a large and long literature supporting NIT rules. ${ }^{14}$ The advantage of a NIT rule is that it has implicit weighting on both prices and output. Moreover, in its growth rate form, it applies equal weights to inflation and output growth: both can be shown to be equal to $\alpha$.

NIT rules respond to demand shocks in the same direction as inflation targeting; i.e., raising interest rates in the face of a positive demand shock. However, the magnitude of the change may be different from inflation targeting since the rule includes implicit weighting of output changes as well as inflation. Under the NIT approach, there is no need for the existence of "divine coincidence" (Blanchard and Gali, 2007) for the output and price stability objectives to be achieved in the face of demand shocks (Bean, 1983; Rogoff, 1985; Ball and Mankiw, 1994; Frankel, 20I2; McKibbin, 20I5).

The main difference between nominal income and inflation targeting is the rule's response to a shock to aggregate supply. As inflation rises and output falls under an aggregate supply shock, a

\footnotetext{
${ }^{14}$ See Meade (1977), Bean (1983), Gordon (1985), McCallum (20II, 2015), Henderson and McKibbin (1993), Frankel (20I2), Sumner (20I4), Woodford (20I2), Beckworth and Hendrickson (20I6)
} 
NIT rule weights the changes equally. For example, a central bank facing a shock that raised the price level and reduced output by equal percentages, thus leaving nominal GDP unchanged, would leave the interest rate unchanged. Thus, the major advantage of nominal GDP targeting highlighted in the literature is that it gives the central bank the ability to handle permanent supply shocks with close to optimal monetary policy outcomes (Rogoff, 1985; Henderson and McKibbin, 1993; Frankel, 2012; Garin et al., 20I5). In the case of a persistent change in trend real growth, the implication of not changing the nominal GDP target would be a permanent change the rate of inflation.

\section{JOINTLY OPTIMIZING CLIMATE AND MONETARY POLICIES}

Having reviewed the basics of both climate policy and monetary policy, we now consider the interactions between the two. Following that, we discuss the implications of extreme weather events and other climatic disruptions for joint management of climate and monetary policy.

\section{Climate Policies}

This section examines each climate policy regime to consider the implications of each major monetary policy for that particular climate policy regime. In sum, the carbon policies (again, shorthand for potentially broader GHG policies) are: a carbon tax; a permit trading system; and regulatory responses. The monetary rules are: strict inflation targeting; flexible inflation targeting; price level targeting; Henderson-McKibbin-Taylor rules; and nominal income targeting.

\section{Carbon Taxes}

From a monetary perspective, a carbon tax is a complex aggregate supply shock. On one hand, the tax increases costs in the fossil energy sector and thus reduces the total output that can be produced for a given set of primary factors. On the other hand, if revenue from the tax is used to lower other distortionary taxes, that component of the policy would be a supply shock in the other direction, lowering costs and increasing potential output. To keep things simple, in the discussion below we will assume that the net macroeconomic impact, not accounting for the environmental benefits of the policy, is negative; that is, that any positive supply impacts from reductions in other taxes are not sufficient to fully offset the negative impact of the carbon tax itself. Thus, real output may return to its baseline rate of growth but the level of output would be lower at each point in time relative to what it would have been.

First consider a simple scenario. Suppose a central bank has set a target rate of inflation at 3 percent per year and has been achieving it for several years. The government then imposes a carbon tax that takes effect immediately (at $t=0$ ), has not been anticipated by private agents, and once established is held constant indefinitely. Overall economic output would decline and inflation would spike up. 
With no response by the central bank, and assuming that private agents recognize that the policy is effectively a one-time change in relative prices and thus do not expect subsequent changes in the underlying inflation rate, the inflation rate would quickly return to its original level and the price level would step up to a higher level overall. The relative price of carbonintensive goods would be permanently higher. The level of real output would be permanently lower but the rate of growth of real output would return to baseline. Figure 3 shows the pattern of impacts on the aggregate price level and the inflation rate over time. Note that for clarity, the figure shows a 10 percent increase in the price level at the onset of the tax. Most carbon taxes that have been proposed would have a smaller impact on aggregate prices.

Figure 3: Price Level and Inflation Rate Impacts of a Simple Carbon Tax
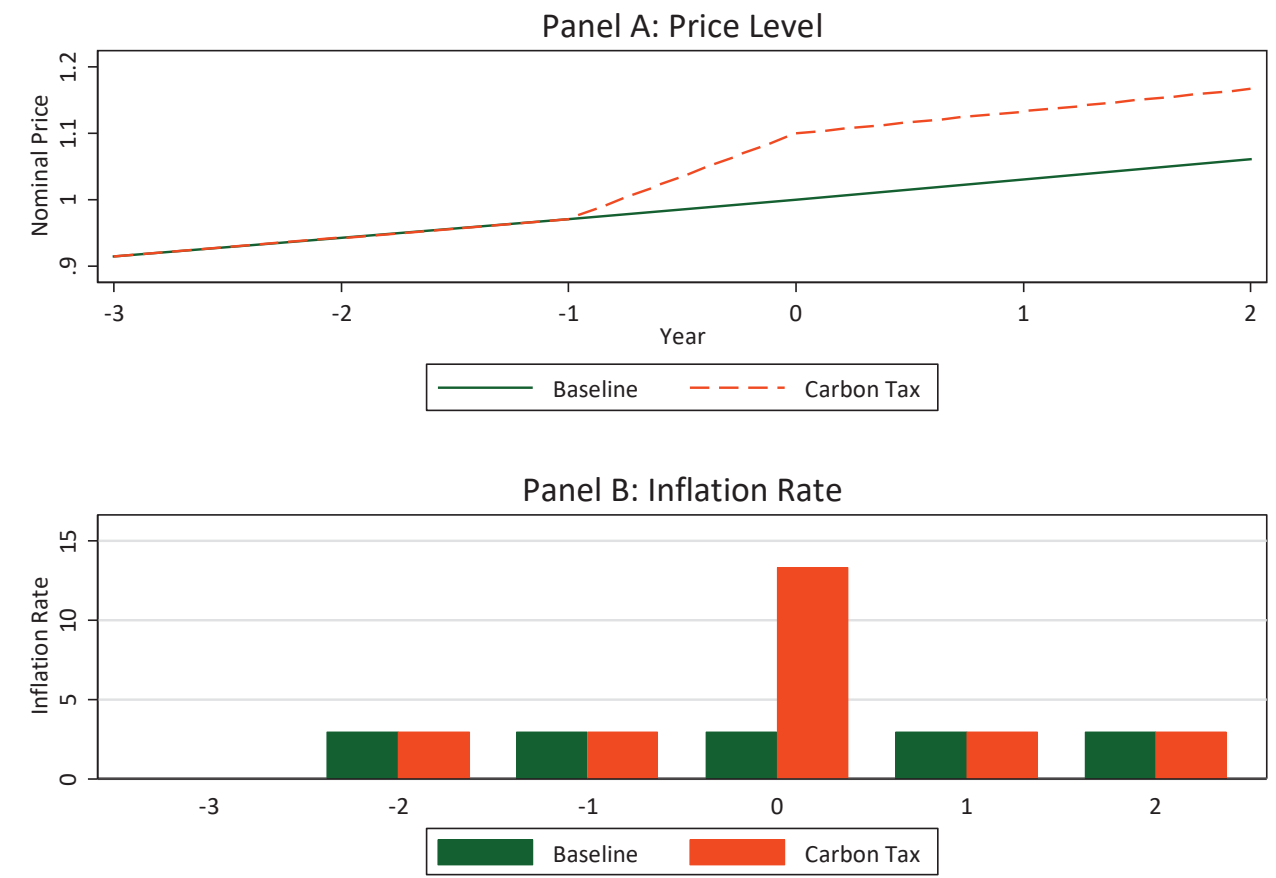

Now consider various ways a central bank might respond to this one-year spike in inflation. A central bank using strict inflation targeting would see the inflation spike at $t=0$ and respond by raising the interest rate. That would slow the economy further than the carbon tax did on its own, and it would also cause the exchange rate to appreciate, making imported goods cheaper but exports uncompetitive. Both impacts would reduce the underlying inflation rate in the economy, partially offsetting the increase in overall inflation caused by the tax. However, the decline in output would be worse than if the central bank had not responded. Moreover, lags in the propagation of interest rate changes through the economy could easily cause the impact of the rate increase to occur at $t=1$ or later, when inflation would otherwise have returned to baseline. 
A central bank using FIT might avoid exacerbating the output effect of the tax if it recognized that the carbon tax was a one-time step in the price trajectory and did not change interest rates. In practice, however, fluctuations in the economy from year to year will mean that the bank may have difficulty separating the impact of the carbon tax from that of other events that may have caused it to miss its target for year 0 . For example, Figure 4 extends the scenario in Figure 3 by adding random year-to-year fluctuations in the bank's achievement of its target inflation rate. In year 0 , part of the deviation in the inflation rate from the target is due to baseline discrepancies that are independent of the tax (that is, the baseline bar for year 0 in panel $B$ exceeds the target bar), and in year I, all of the deviation in inflation is due to the baseline and none is due to the tax. A central bank that was aware of the tax and was using FIT would want to raise interest rates slightly in year 0 and somewhat more in year I to offset the baseline component of the inflation rate. However, it would be challenging in practice to separate the baseline component from the portion due to the carbon tax. Without understanding the interaction of monetary and climate policies, the bank may mistake all of the inflation in year 0 for a baseline deviation and thus raise interest rates far more than would be desirable.

Figure 4: A Simple Carbon Tax with Underlying Baseline Disturbances
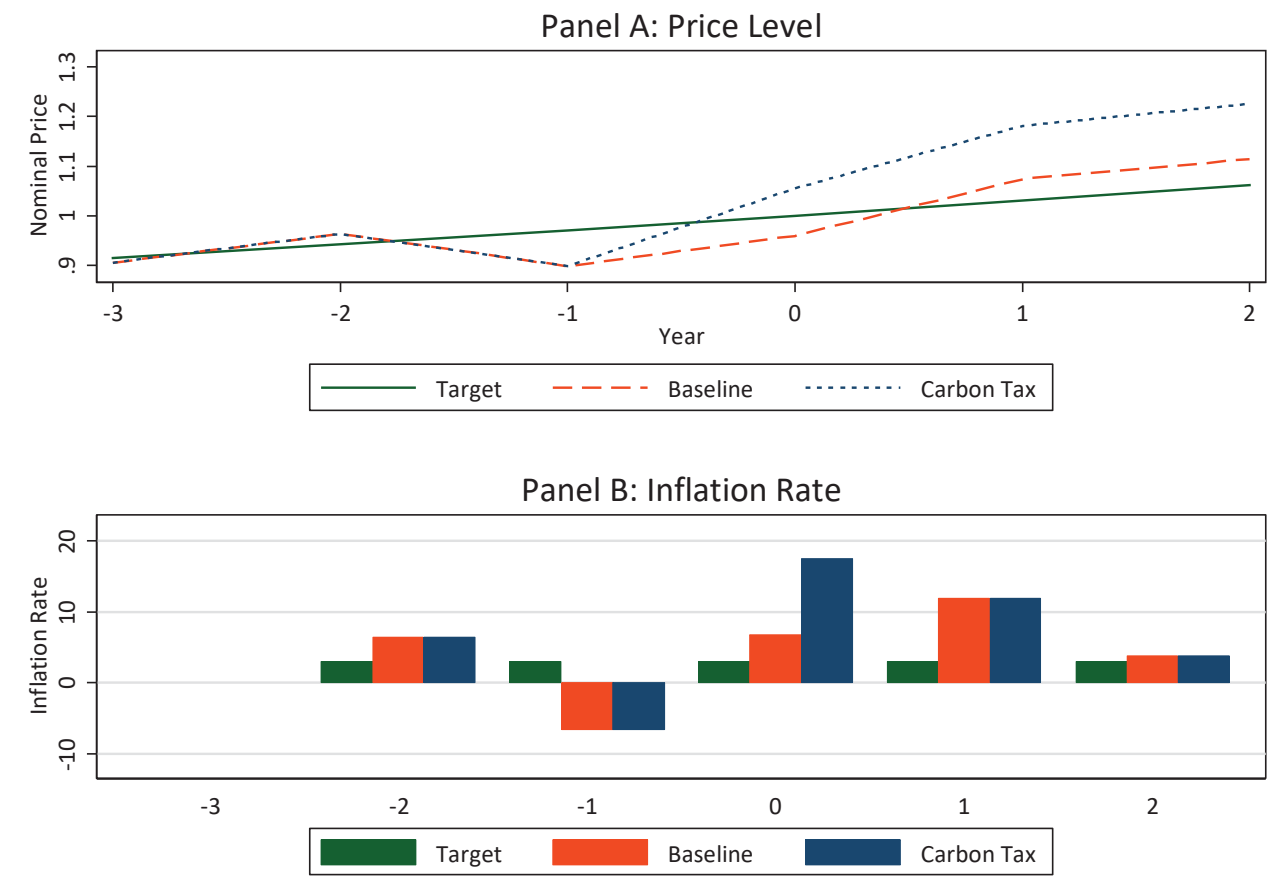

Understanding the nature of the climate policy response would be even more critical for a central bank using PLT. Without an appropriate rule, the bank would not only offset the 
inflation shock but would tighten monetary policy even further in order to return the price level back to the original trajectory.

If the bank does not understand the nature of the carbon abatement policy, both HMT and NIT (as automatic rules) would perform better than inflation targeting because they would tighten monetary policy less. A central bank using an HMT rule would weigh the rise in inflation against the fall in output, and it would thus raise interest rates less than a bank using inflation targeting. The bank might even lower interest rates if the rule's weight on output or the output decline itself were sufficiently large. Similarly, a central bank using an NIT rule would implicitly account for the fall in output: although $P$ would rise, the decline in $Y$ would mean that $P Y$ would rise less than $P$ alone would suggest.

In practice, a critical element in determining how a central bank would react would be the bank's assessment of inflationary expectations. This is particularly important because the most likely carbon tax policy is not a single once-and-for-all step, but rather an initial step followed by a rise in the carbon tax rate in real terms over time. This is more complicated for the central bank because the shock potentially changes the rate of inflation as well as the price level, and possibly changes the rate of growth of actual and potential output as well. Figure 5 shows an example with a carbon tax that rises at 4 percent per year in real terms. The key difference from Figure 3 is that, in the absence of an intervention by the central bank, the carbon tax would cause a permanent deviation in the inflation rate. Accommodating the carbon tax policy would thus require that the bank raise its target inflation rate. However, doing so is relatively straightforward since the carbon tax is known in advance. The bank could anticipate the impact it would have on the inflation rate and adjust its target accordingly. 
Figure 5: Price and Inflation Impacts of a Carbon Tax Increasing Over Time

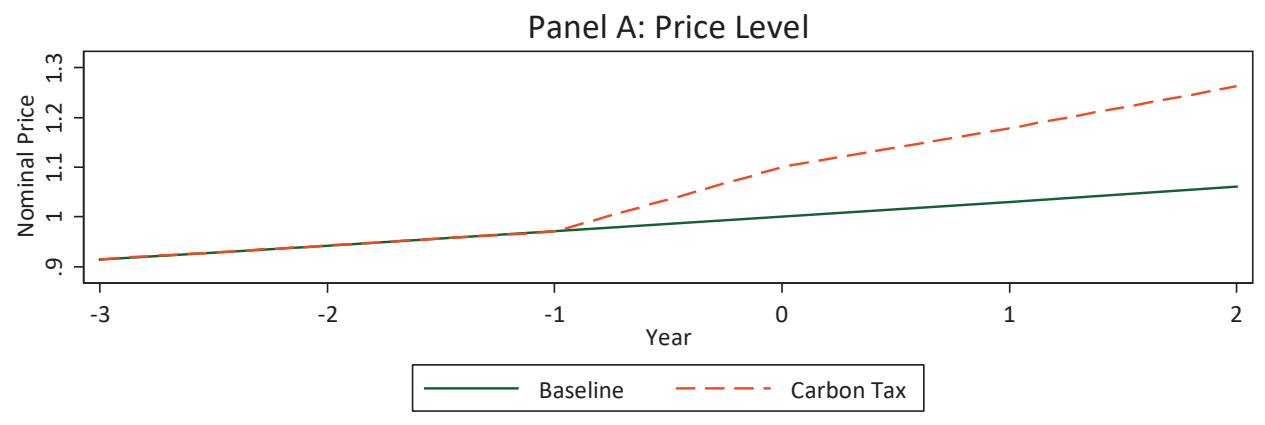

Panel B: Inflation Rate

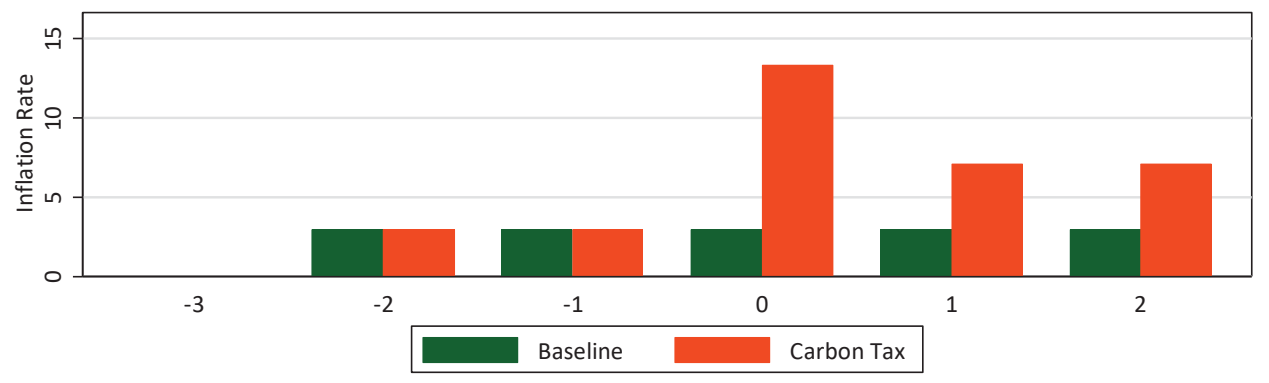

Tradeable Emission Permits

The issues discussed for the interaction of the carbon tax with the monetary regime would also apply under a tradeable permit policy. However, the main difference is that future trajectory of permit prices would be less certain than the carbon tax (which would be set explicitly in the policy). Permit prices would be uncertain for two at least reasons: (I) uncertainties in the marginal cost of abatement at the emissions limit; and (2) variations in economic conditions that affect the demand and supply of fossil energy. As a result, the impact of the policy on prices would be uncertain, and it would thus be more difficult for the central bank to adjust monetary policy to deal with the volatility of prices generated by the permit trading system.

\section{Hybrid Policy}

The advantage of a hybrid policy over a permit trading system would be that the carbon price in the short term would have the same predictability as the carbon tax as long as the ceiling price was binding (which it would be designed to be in practice). The long term expected carbon price would be clear from the long-term permit market. Depending on the length of time of the fixed price on a hybrid policy, the problems for the central bank would be smaller than in a more volatile trading system. 


\section{Regulatory and Other Responses}

Relative to a carbon pricing policy, regulations, subsidies, and standards to control GHG emissions would be more difficult for a central bank to anticipate and respond to since the effects on output and prices would be opaque and hard to predict. This would be true under each monetary rule because of the challenge in assessing the consequences of such policies on current and potential output and current and expected inflation.

\section{Climatic Disruption and Output Volatility}

There is strong empirical evidence that extreme weather events reduce economic growth (Cavallo and Noy, 2010) in the short run. For example, droughts and floods can disrupt agricultural activity and damage crops (Gandhi and Cuervo, 1998). Extreme weather can also reduce effective labor supply due to climate-induced health impacts (Fankhauser and Tol, 2005), and it can increase the rate of capital depreciation (Stern, 2013). In short, as climate disruption leads to more frequent (or more damaging) extreme weather events, monetary policymakers will need to respond to more frequent (or larger) negative supply shocks.

A central bank following strict inflation targeting would react to an extreme weather event by tightening monetary policy to stem the rise in inflation. A bank following PLT would react even more strongly, raising interest rates enough to reduce the price level back down to its target. In both cases, the bank would worsen the impact of the shock on economic activity.

A central bank using FIT might avoid exacerbating the fall in output if it accounted for the transitory nature of the event and chose to use its discretion to adjust the timing of policy adjustment. However, its task would be made difficult by imperfect real-time measurement of the output gap (Orphanides 2000). There is substantial evidence indicating that the Fed's estimates of the output gap under normal economic conditions have been prone to large errors (Orphanides 2000, 2004; Sumner, 20I4).

For example, using a New Keynesian model with imperfect information, Beckworth and Hendrickson (2016) show that the Fed's output gap forecasts over 1987-2007 explain only I 3 percent of the fluctuations in the actual output gap. Estimates during periods of unusually persistent and unpredictable productivity shocks, as would be the case with increased climatic disruption, could be even worse. ${ }^{15}$ For example, according to the OECD (2014), forecast performance was very poor during the Great Recession, with large forecast errors observed for most OECD central banks during the period 2007-2012. In general, more frequent or intense shocks makes inflation forecasting more difficult for both the central bank and private actors, which erodes the rationale for basing monetary policy primarily on inflation forecasts.

\footnotetext{
${ }^{15}$ Some argue that the output gap could be "environmentally adjusted" to account for large climate-induced productivity shocks that could reduce the economy's potential output (Lacunza, 2008; Batten et al., 2016). However, scientific understanding of the nature and persistence of climate shocks is not sufficient to allow this to be done routinely at present.
} 
In contrast, a central bank using an HMT or NIT rule would respond to extreme weather shocks by balancing the rise in prices against the drop in economic output caused by the event. As with the onset of a carbon tax, such a central bank would be less likely than an inflationtargeting bank to exacerbate the damage to the economy. However, implementing an HMT rule in a changing climate would be challenging for the reason mentioned above: an increase in the frequency of extreme weather events raises the difficulty of forecasting potential output and therefore the output gap.

An advantage of NIT is that the central bank using NIT does not need to have a precise estimate of the output gap because only the nominal income target is announced. As a concrete example, suppose the growth rate of potential output is estimated by the central bank to be $3 \%$ per year and the desired inflation rate is 3\%. The nominal income target growth rate for a central bank with a NIT rule would therefore be the sum of the two: $6 \%$. Now suppose that an extreme weather event causes potential output growth to fall to $2.5 \%$ over the forecast period, meaning that the event reduces potential output by $0.5 \%$. If the NIT central bank achieves its $6 \%$ nominal income target, output growth would be $2.5 \%$ and the inflation rate would be $3.5 \%$. Inflation would have exceeded the bank's preferred value of $3 \%$. However, the discrepancy is too small to undermine the expectation of private agents and financial markets that the bank is committed to a clear rule. That means that with NIT, the bank limits the rise in expectations of higher inflation, preventing a wage-price spiral. Indeed, the central bank does not even need to observe or account for the precise nature of the shock: simple adherence to the policy rule gives a reasonable policy response. Thus, rules like NIT that do not rest on output gap calculations are better for promoting macroeconomic stability than those that do, especially during periods of with an unusual number of supply side macroeconomic shocks.

\section{Climatic Disruption and Financial Stability}

Some analysts are also concerned that climatic disruption, and the policy responses to it, can weaken financial stability ${ }^{16}$ (Carney, 2015; Bank of England, 2015), which some authors argue should be an additional responsibility of central banks. Although the empirical evidence on how extreme weather events affect financial stability remains mixed, some believe severe and persistent climate-induced natural disasters pose serious risks to the stability of the financial system (Bank of England, 20I5; Carney, 20I5). According to the Bank of England (2015), apart from the climate-induced physical risks ranging from severe weather events like flooding, droughts, and disruption of agricultural productivity, insurance firms face losses from climate damages that they may not be able to fully diversify. The potential for abrupt constraints on GHG emissions can also pose risks to financial assets and the balance sheets of fossil energy

\footnotetext{
${ }^{16}$ Stability of the financial system in the short run may differ significantly from the stability of output and employment. For example, when debt contracts are secured by assets priced in nominal terms, sharp changes in the price level can trigger widespread cascades of asset sales, temporarily driving asset prices down much further than the initial changes in output and employment would warrant.
} 
companies. Highly ambitious climate policy could strand capital and weaken the profitability of firms (Dafermos, et al. 2016), but policymakers will take such outcomes into account in their decisions about which policies to adopt.

Research is emerging on how monetary policy could foster climate-related financial stability, with some advocates arguing for 'green' quantitative easing (QE) arrangements by many central banks (Murphy and Hines, 2010; Campiglio, 2016). ${ }^{17}$ Apart from the use of QE programs, some argue for the inclusion of financial stability as a permanent monetary policy objective, particularly in an economy prone to persistent supply shocks that endanger financial stability (Cecchetti et al., 2000; Woodford, 2012). However, the longstanding argument (Bernanke and Gertler, 1999, 200I; Bank of England, 2015) remains that monetary policy should focus on the traditional goals of price and output stability, with financial stability concerns best handled by regulatory tools such as macroprudential policies.

Sheedy (2014) provides strong empirical evidence that when debt contracts are written in nominal terms, NIT outperforms FIT by improving financial market risk allocation mechanisms, particularly by insulating households' nominal income from shocks even when there is short-run price stickiness. Sheedy argues that since borrowers' abilities to meet their obligations is more related to their income, a monetary policy rule that puts more weight on nominal income than price stability is best suitable in addressing asset price bubbles like those that could result from the short-run consequences of a carbon tax (i.e. stranded asset risks). Using a model with default probabilities and bankruptcy costs, Koenig (20I3) also reached similar conclusion, strongly upholding the view that in an economy with adverse supply shocks and nominal debt contracts, targeting nominal income is the optimal monetary policy approach to containing asset price risks.

\section{CONCLUSION}

This paper has argued that in a carbon-constrained and climatically-disrupted world, there are important linkages between the climate change and monetary policy regimes. We discuss three relevant connections. First, the question arises how central banks should anticipate and respond to inflation increases and output decreases that result from climate policy. Responding solely to the inflationary component would lead to larger output losses than using a monetary policy rule that also aims to keep output and employment high. In particular, we argue that national income targeting is an attractive approach. It avoids creating public expectations of higher future inflation, and it does not require the central bank to understand the precise nature of the climate policy shock; simple adherence to the policy rule provides a reasonable policy response.

\footnotetext{
${ }^{17}$ Some argue that central banks can address credit market failures that impede low carbon investments by expanding their balance sheets with the securities of entities engaged in low-carbon activities (e.g., bonds of renewable energy firms). Campiglio (2016)
} 
Moreover, national income targeting is less vulnerable to imprecise information about the current state of the economy than many other monetary policy rules.

Second, the design of climate policy can significantly affect how easily central bankers can respond to the direct and indirect effects of the policy. Fluctuating allowance prices under a cap and trade policy would make inflation forecasting more difficult for central banks than a policy such as a carbon tax or a hybrid approach in which carbon prices are more stable and predictable. Thus, a carbon tax or a hybrid policy with stable short term carbon prices would simplify the response of a central bank to economic shocks relative to a more volatile carbon pricing approach.

Finally, a third challenge is that climatic disruption will increase the frequency and severity of negative supply shocks, making it more difficult for central banks to forecast output gaps, and therefore to forecast inflation, a key part of some monetary policy frameworks. We conclude that nominal income targeting, which does not rely on such forecasts, is better suited to a climate-disrupted world than other monetary rules.

Overall, the interaction between climate policy and monetary policy suggests that the two be chosen jointly. Considering each regime separately can easily lead to policies that seem fine in isolation but that perform poorly in practice. 


\section{REFERENCES}

Alves, S. A. L. (20I5). Lack of Divine Coincidence in New Keynesian Models. Journal of Monetary Economics, 67:33-46

Amano, R., Engle-Warnick, J. and Shukayev, M. (20I I). Price-Level Targeting and Inflation Expectations: Experimental Evidence. Bank of Canada Working Paper No. 201 I-18

Ball, L. and Mankiw, N. G. (1995). Relative-Price Changes as aggregate supply shocks. The Quarterly Journal of Economics, 161-193

Bank of England (20I5), The impact of climate change on the UK insurance sector: a climate change adaptation report by the Prudential Regulation Authority. http://www.bankofengland.co.uk/pra/documents/supervision/activities/pradefra09I5.pdf

Bank of England (20I7). The Bank of England's response to climate change, Quarterly Bulletin, 2017 Q2

Batten, S., Sowerbutts, R. and Tanaka, M. (2016). Let's Talk about the Weather: the impact of climate change on central banks. Bank of England Staff Working Paper No. 603

Bean, C. R. (1983). Targeting Nominal Income: An Appraisal. The Economic Journal, 93(372): 806-819

Beckworth, D. and Hendrickson, J. R. (2016). Nominal GDP Targeting and the Taylor Rule on an Even Playing Field. Mercatus Working Paper

Bernanke, B S. and Gertler, M. (1999). Monetary policy and asset price volatility, Federal Reserve Bank of Kansas City Economic Review 84, I7-5I.

Bernanke, B S. and Gertler, M. (200I). Should Central Banks Respond to Movements in Asset Prices? American Economic Review, 9 I (2): 253-257.

Bernanke, B. S., Laubach, T., Mishkin, F. S., and Posen, A. S. (1999). Inflation targeting: Lessons from the international experience. Princeton, N.J.: Princeton University Press.

Bernanke, B. S. (2007). Inflation Expectations and Inflation Forecasting, Speech delivered at the Monetary Economics Workshop of the National Bureau of Economic Research Summer Institute, Cambridge, Massachusetts.

https://www.federalreserve.gov/newsevents/speech/bernanke200707/ 0a.htm

Bernanke, B. S. (20I5). The Taylor Rule: Benchmark for Monetary Policy? https://www.brookings.edu/blog/ben-bernanke/20I5/04/28/the-taylor-rule-a-benchmark-formonetary-policyl

Bernanke, B. S. (2017). Monetary Policy in a new era. https://www.brookings.edu/wpcontent/uploads/2017//0/bernanke_rethinking_macro_fin al.pdf

Blanchard, O. and Gali, J. (2007). Real Wage Rigidities and the New Keynesian Model, NBER Working Paper No. II 806

Blanchard, O. (2016). The US Phillips Curve: Back to the 60s? American Economic Review, 106(5): $31-34$ 
Campiglio, E. (2016). Beyond carbon pricing: the role of banking and monetary policy in financing the transition to a low-carbon economy. Ecological Economics, I21, 220-230.

Carney, M (2015). Breaking the tragedy of the horizon - climate change and financial stability, Speech delivered at at Lloyd's of London, 29 September 2015. http://www.bankofengland.co.uk/publications/Documents/speeches/2015/speech844.pdf

Cavallo, E. A. and Noy, I. (20I0). The economics of natural disaster: a survey IBD Working Paper Series, No. 124

Cecchetti, S. G., H. Genberg, J. Lipsky, and S. Wadhwani. 2000. Asset Prices and Central Bank Policy. Geneva Reports on the World Economy No. 2, International Center for Monetary and Banking Studies, Geneva.

CBO (20I3). Effects of a Carbon Tax on the Economy and the Environment. Available at: https://www.cbo.gov/sites/default/files/I I 3th-congress-20 I320I4/reports/44223_Carbon_0.pdf

Dafermos, Y., Nikolaidib, M. and Galanisc, G. (2016). Climate change, financial stability and monetary policy http://www.carbontracker.org/wpcontent/uploads/2015/II/CAR38I7_Synthesis_Report_24.II.I5_WEB2.pdf

Fankhauser, S and Tol, R. S. J. (2005). On climate change and economic growth', Resource and Energy Economics 27:1-17

Feldstein, M. (2006). The Effect of Taxes on Efficiency and Growth, NBER Working Paper No. $1220 \mid$

Harrison Fell, Dallas Burtraw, Richard D. Morgenstern, Karen L. Palmer, Soft and hard price collars in a cap-and-trade system: A comparative analysis, Journal of Environmental Economics and Management, Volume 64, Issue 2, 2012, Pages I83-I 98.

Frankel, J. (20I2). The Death of Inflation Targeting. https://www.projectsyndicate.org/commentary/the-death-of-inflation-targeting?barrier=accessreg

Frankel J. (2013) "Nominal-GDP Targets, Without Losing the Inflation Anchor," in Richard Baldwin and Lucrezia Reichlin, eds., Is Inflation Targeting Dead: Central Banking After the Crisis (Centre for Economic Policy Research: London, 2013), 90-94.

Gandhi, V. P. and Cuervo, J. (1998). Carbon Taxes: Their Macroeconomic Effects and Prospects for Global Adoption: A Survey of the Literature, IMF Working Paper No. 98/73

Garin, J., Lester, R. and Sims, E. (20I5). On the desirability of nominal GDP targeting, Journal of Economic Dynamics and Control, 69:2I-44

Giannoni, M., and M. Woodford (2004). "Optimal Inflation Targeting Rules," in B. S. Bernanke and M. Woodford (eds.), The Inflation-Targeting Debate. Chicago, III.: University of Chicago Press

Goulder, L. H., Parry, I. W. H., and Burtraw, D. (1997). Revenue-Raising versus Other Approaches to Environmental Protection: The Critical Significance of Preexisting Tax Distortions. The RAND Journal of Economics, 28(4):708-73 I 
Henderson, D. W. and McKibbin, W. J. (1993). A Comparison of Some Basic Monetary Policy Regimes for Open Economies: Implications of Different Instrument Adjustments and Wage Persistence. International Finance Discussion Papers No. 458

Kim, Bae-Geun. (2016). Supply Shocks and the Divine Coincidence. Economics Letters 145: 210 213

King, M. (1997). Changes in UK monetary policy: Rules and discretion in practice. Journal of Monetary Economics, 39(I): 8I-97

Koenig, E. F. (2013). Like a Good Neighbor: Monetary Policy, Financial Stability, and the Distribution of Risk. International Journal of Central Banking, 9(2): 57-82

Lacunza, H. (2008). Monetary Policy and Climate Change: Is There a Role for the Central Bank? Speech delivered at BIS International Conference (2008). http://storage.jakstik.ac.id/ProdukHukum/BankIndonesia/HernanLacunzapdf.pdf

Marron, B. and Toder, E. J. (20I4). Tax Policy Issues in Designing a Carbon Tax, American Economic Review, 104(5): 563-568

McCallum, B. (20I I). Nominal GDP Targeting. http://shadowfed.org/wpcontent/uploads/20 I I/I0/McCallum-SOMCOct20 I I.pdf

McCallum, B. (2015). Nominal GDP targeting: Policy rule or discretionary splurge? Journal of Financial Stability, 17: 76-80

Meade, J. (1978). The Meaning of "Internal Balance. The Economic Journal, 88(35I): 423-435.

Metcalf, G. E. (2007). A Proposal for a U.S. Carbon Tax Swap: An Equitable Tax Reform to Address Global Climate Change. The Hamilton Project.

McKibbin W. (2012) A New Climate Strategy Beyond 2012: Lessons from Monetary History 2007 (final version of the Shann Memorial Lecture), The Singapore Economic Review, Vol. 57 , No. 3, 18 pages

McKibbin, W. J. (20I5). Central Banks Must Target Growth Not Inflation https://www.brookings.edu/opinions/central-banks-must-target-growth-not-inflation/ McKibbin, W. J. and P. J. Wilcoxen (2002). Climate Change Policy After Kyoto: A Blueprint for a Realistic Approach, Washington: The Brookings Institution.

McKibbin, W. J., Morris, A. C., Wilcoxen, P. J. and Cai, Y. (20I2). The Potential Role of a Carbon Tax in US Fiscal Reform, The Brookings Institution. https:/www.brookings.edu/wp-content/uploads/2016/06/carbon-tax-mckibbin-morriswilcoxen.pdf

McKibbin W and Wilcoxen P (20I3), A Global Approach to Energy and the Environment: The G-cubed Model" Handbook of CGE Modeling, Chapter 17, North Holland, Pp 995- 1068

McKibbin, W., Morris, A. and P. Wilcoxen (2009) "Expecting the Unexpected: Macroeconomic Volatility and Climate Policy", in J. Aldy and R. Stavins (eds) Post Kyoto International Climate Policy: Implementing Architectures for Agreement, Cambridge University Press, New York, pp. 857 - 888. 
McKibbin W. J., Morris, A., and Wilcoxen P. J. (20I4)" The Economic Consequences of Delay in U.S. Climate Policy”, Brookings Discussion Paper in Climate and Energy Economics, June 3.

McKibbin W. J., Morris, A., Wilcoxen P. J., and Y. Cai (20I5) "Carbon taxes and US Fiscal Reform." The National Tax Journal, Vol 68, no I March, National Tax Association, Washington DC ppI39-156

Murphy, R. and Hines, C. (2010). Green quantitative easing: paying for the economy we need. Finance for the Future, available at: http://www.financeforthefuture.com/GreenQuEasing.pdf.

Nordhaus, W. D. (1993). Optimal greenhouse-gas reductions and tax policy in the 'DICE' model, American Economic Review 83: 313-317.

Nordhaus, W. D. (20I4). Estimates of the Social Cost of Carbon: Concepts and Results from the DICE-20I3R Model and Alternative Approaches, Journal of the Association of Environmental and Resource Economists, I: 273-3 I2

Orphanides, A. (2000). Activist Stabilization Policy and Inflation: The Taylor Rule in the 1970s. Working Paper, Board of Governors of the Federal Reserve System

Orphanides, A. (2004). Monetary Policy Rules, Macroeconomic Stability, and Inflation: A View from the Trenches." Journal of Credit, Money and Banking 36 (2): I5I-75.

Pearce, D.W. (199I). The Role of Carbon Taxes in Adjusting to Global Warming. Economic Journal I0I (I99I): 938-48.

Pindyck, R. S. (2013). Climate Change Policy: What Do the Models Tell Us?'. Journal of Economic Literature, $5 \mathrm{I}(3): 860-872$

Pindyck, R S (20I5). The use and misuse of models for climate policy. NBR Working Paper No. 21097

Poole, W. (1972)" Optimal Choice of Monetary Policy Instruments in a Simple Stochastic Macro Model, The Quarterly Journal of Economics, Vol. 84, No. 2 (May, 1970), pp. 197-216

Rogoff, K. (1985). The Optimal Degree of commitment to an intermediate monetary target. The Quarterly Journal of Economics, I 169-1 189

Røisland, O. (200I). Institutional Arrangements for Monetary Policy When Output Is Persistent, Journal of Money, Credit and Banking, 33(4):994-I0I4.

Sheedy, K. D. (2014). Debts and Incomplete Financial Markets: A Case for Nominal GDP Targeting, Brookings Papers on Economic Activity, Spring: 30I-36I.

Stern, N. (20/3). The Structure of Economic Modelling of the Potential Impacts of Climate Change: Grafting Gross Underestimation of Risk onto Already Narrow Science Models, Journal of Economic Literature 5I (3): 838-59.

Sumner, S. B. (20I4). NGDP Targeting: A Simple Rule to Improve Fed Performance, Cato Journal, 34(2): 315-337

Svensson, L. E. O (1996). Inflation Forecast Targeting: Implementing and Monitoring Inflation Targets. NBER Working Paper No. 5797 
Svensson, L. E. O. (1998). Inflation Targeting as a Monetary Policy Rule, NBER Working Paper No. 6790

Svensson, L. E. O. (2003). Escaping from a Liquidity Trap and Deflation: The Foolproof Way and Others, Journal of Economic Perspectives, 17(4): I45-166.

Taylor, J. B. (1993). Discretion versus Policy Rules in Practice, Carnegie-Rochester Series on Public Policy 39, 195-214

Woodford, M. (20I2). Inflation Targeting and Financial Stability NBER Working Paper No. 17967 